\title{
Clinical, Hematological and Biochemical Profiles of Dogs with Leishmania infantum
}

\author{
Stela Maria Argôlo Montargil', Fábio Santos Carvalho', Gabriela Mota Sena de Oliveira', \\ Alexandre Dias Munhoz², Renata Santiago Alberto Carlos² \& Amauri Arias Wenceslau²
}

\begin{abstract}
Background: Canine Visceral Leishmaniasis is a zoonosis affecting dogs worldwide. Its epidemiological importance is observed in Brazil, wherein the largest number of cases originates in the Northeast Region of the country. The disease is caused by the etiologic agent Leishmania chagasi (= infantum) and transmitted by an invertebrate form of sand fly of the genus Lutzomia. Domestic dogs are one of the main reservoirs. The aim of this study was to use molecular analysis to diagnose dogs naturally infected with Leishmania spp. in the city of Jequie, State of Bahia, Brazil, and to describe the clinical signs, as well as the hematological and biochemical profiles associated with these cases.

Materials, Methods \& Results: In the present study, 198 dogs underwent physical examination and had blood samples collected for hematological, biochemical and PCR tests for Leishmania infantum. Two primers have been used for the molecular diagnostic technique (PCR): first, the ITS-1 specific to Leishmania species followed by the PCR-RFVL to identify the genus; and second, the primer pair RV1/RV2 specific to the Leishmania infantum species in all the samplesAmong the 198 samples collected, four animals tested positive for the Leishmania infantum via PCR, two of which were symptomatic and two asymptomatic. Among the symptomatic animals, animal one presented with diffuse alopecia, ulcerated lesions on the tip of the ears, ophthalmopathy, onychogryphosis, cachexia, anemia and neutrophilic leukocytosis, and animal two presented with alopecia, pustules, crusting, diffusely-spread erythema, anemia, hyperproteinemia, thrombocytopenia and azotemia. Among the two asymptomatic dogs, one animal had anemia, hyperproteinemia, thrombocytopenia, leukocytosis with neutrophilia, and azotemia; the other animal's laboratory findings revealed hyperproteinemia and leukocytosis with neutrophilia. Discussion: Although 48 animals presented clinical signs, as well as hematological and biochemical alterations commonly reported in the available literature on Leishmaniasis, only two tested positive by PCR. This implies that a positive diagnosis for this pathology should not be given only based on nonspecific clinical and laboratory data. On the other hand, two animals positive via PCR were asymptomatic, and could act as silent disseminators of the parasite in the region. Since the region is considered endemic for the disease, many dogs may be in the chronic phase, with low parasitemia. The fact that blood with low parasitemia was examined may have influenced the estimate of the ocurrence, as it is common knowledge that in such cases the PCR can deliver a false-negative result due the low amount of DNA for amplification. The ideal tissue should be obtained from the spleen, liver, lymph nodes or via bone marrow puncture. However, it was not possible to collect this kind of tissue due to the need for general anesthesia, which is a limiting factor when the study is conducted with domiciliated animals. Clinical signs found in positive animals involve different systems, due to the multisystemic nature of the disease, and evaluation for differential diagnosis is essential to rule out other pathologies that lead to similar changes, such as systemic lupus erythematosus, ehrlichiosis, and babesiosis, among others. Some of the hematologic changes found in positive animals included: anemia, hyperproteinemia, leukocytosis; all of which are respectively correlated with spinal cord dysfunction, splenic sequestration and hyperglobulinemia due to the intense immune response. We concluded that the PCR enabled the identification of canine visceral leishmaniasis cases in the city of Jequié. However, our study did not identify a relationship between the molecular positivity of dogs to Leishmania infantum and the clinical signs and the hematologic and biochemical analysis of samples from suspected cases.
\end{abstract}

Keywords: zoonosis, molecular diagnosis, symptomatology, DNA sequence.

${ }^{1}$ Curso de Pós-graduação em Ciência Animal (PPGCA), Universidade Estadual de Santa Cruz (UESC), Ilhéus, BA, Brazil. ${ }^{2}$ Departamento de Ciências Agrárias e Ambientais, Curso Medicina Veterinária, UESC, Ilhéus, BA, Brazil. CORRESPONDENCE: A.A. Wenceslau [wenceslau @uesc.br - Tel.: +55 (73) 3680-5406]. Universidade Estadual de Santa Cruz, Departamento de Ciências Agrárias e Ambientais, Colegiado de Medicina Veterinária. Rodovia Ilhéus-Itabuna, km 16. Salobrinho. CEP 45662-900 Ilhéus, BA, Brazil. 


\section{INTRODUCTION}

Visceral leishmaniasis is a disease caused by protozoa of the Leishmania genus, and its main species in Brazil include: L. infantum, L. chagasi, L. mexicana and L. donovani [22]. These parasites are transmitted both to animals and to humans through the bite of dipteral insects of the genus: Phlebotomus sp. and Lutzomia longipalpis [18].

The disease affects dogs worldwide and has been observed and described in 12 Latin American countries [4]. Its reporting has been mandatory in Brazil since 1978, and its occurrence has been reported across all geographic regions, with higher incidence in the Northeast [16].

Dogs play a major role in the cycle of the parasites causing both human and canine visceral leishmaniasis, and can be asymptomatic during the dormant phase of infection. The main clinical signs associated with the disease in dogs include: fever, anemia, weight loss, cachexia, onychogryphosis, dermatitis, eye injuries, bleeding disorders and neurological changes [2,21].

The definitive diagnosis can be established by parasitological, serological or molecular methods [2,17,22].

The increasing spread of visceral leishmaniasis is mainly caused by the increase in urbanization in recent years, especially as a particular result of deforestation and population migration [23]. The aim of this study was to diagnose dogs with visceral leishmaniasis in the city of Jequie, in the state of Bahia, which is considered a municipality with high incidence of the disease, and describe the clinical, hematological and biochemical changes in positive animals.

\section{MATERIALS AND METHODS}

\section{Municipality and animals}

The city chosen for collection was the municipality of Jequié, located in the southwestern region of the state of Bahia $\left(13^{\circ} 51^{\prime} 4^{\prime \prime} \mathrm{S} 40^{\circ} 4^{\prime} 52^{\prime \prime} \mathrm{W}\right)$. The area has a tropical, semi-arid climate, with an annual average temperature of $23.3^{\circ} \mathrm{C}$ and an annual temperature range of $5.6^{\circ} \mathrm{C}$; with annual rainfall index of 500 $\mathrm{mm}$. The biome consists strictly of the Caatinga and the Rainforest, within which live an estimated human population of 151,895 inhabitants [10].

The animals were selected by convenience and blood samples were collected from 198 semi-domiciled dogs older than one year, from both genders with no breed predisposition. The total estimated canine population in the city of Jequié was used for sample calculation, with a sampling error of $5 \%$ and estimated prevalence of $20 \%$.

\section{Sample collection}

Epidemiological and individual clinical data were collected by means of a structured questionnaire. After clinical evaluation, $8 \mathrm{~mL}$ of blood was collected through jugular and cephalic vein puncture; $4 \mathrm{~mL}$ thereof was packed in tubes with EDTA anticoagulant for hematologic and molecular analysis, and $4 \mathrm{~mL}$ was packed in tubes without anticoagulant and refrigerated for the biochemical tests. All samples were forwarded to the laboratory of clinical analyses and genetics at the Veterinary Hospital of the State University of Santa Cruz (UESC-VH).

Clinical signs regarded as compatible with leishmaniasis included: fever, anemia, weight loss, cachexia, hepatic and splenomegaly, dermatitis, onychogryphosis, dermatitis, eye injuries, bleeding disorders and neurological changes [2,21].

\section{Hematological and biochemical tests}

The hemogram was carried out in an automatic veterinary hematology analyzer $\left(\mathrm{ABC} \mathrm{Vet}^{\circledR}\right)^{1}$. Total protein was estimated with the aid of a hand-held refractometer. Staining was performed with the Fast $\mathrm{LB}^{2}$ Panoptic kit for the specific analysis of leukocytes, and differentiated leucocyte count was carried out by optical microscopy (Primo Star ZEISS $\left.{ }^{\circledR}\right)^{3}$ on a 100x objective lens.

After the blood tests, the blood samples were centrifuged. The white blood cells and the plasma were then separated and frozen at $-20^{\circ} \mathrm{C}$.

The Labtest ${ }^{\circledR 4}$ kits were used for determination of ALT, AST, blood urea nitrogen (BUN) and creatinine, and these were evaluated in semi-automatic biochemical equipment (BioPlus 2000 $\left.{ }^{\circledR}\right)^{5}$. The reference values used have been previously recommended by other studies [11,12].

\section{Polymerase Chain Reaction (PCR)}

Total DNA extraction was performed on the leukocyte layer using a specific kit (Genomic DNA Purification Wizard $\left.{ }^{\circledR}\right)^{6}$.

Two sets of primers were selected for amplification of the extracted DNA. The first was genera-specific for Leishmania spp. (LITSR/L58S) amplifies 
the ITS-1 region of ribosomal DNA, in which subsequently the cut was made with restriction enzyme HaeIII, for subsequent identification of the species; the second was specific to the Leishmania infantum species (RV1/RV2).

\section{Leishmania spp. PCR (genus-specific)}

The protocol used for the amplification of the ITS-1 region of ribosomal DNA was based on the analysis of the ssU rRNA coding genes and 5.8S rRNA, by primers: LITSR (sense) with sequence 5' CTGGATCATTTTCCGATG 3' and L5.8S (antisense) with sequence 5' TGATACCACTTATCGCACTT 3', resulting in the amplification of a fragment of 300 to $350 \mathrm{pb}$ of the first reaction product [8].

Five microliters $(\mu \mathrm{L})$ of DNA template was used and added to a tube containing $0.2 \mu \mathrm{L}$ of Taq DNA polymerase $^{4}$ at $2 \mu \mathrm{L}$ for each initiator, $1 \mathrm{x}$ buffer containing $\mathrm{MgCl}_{2} 2.5 \mu \mathrm{L}, 1 \mu \mathrm{L}$ of $\mathrm{Mg}, 1 \mu \mathrm{L}$ DNTP, DMSO $1.25 \mu \mathrm{L}$ and $31.05 \mu \mathrm{L}$ of ultrapure water. Amplification conditions on the thermal cycler (Biocycler $\left.{ }^{\circledR}\right)^{7}$ included: initial denaturation at $95^{\circ} \mathrm{C}$ for $3 \mathrm{~min}$, followed by 35 cycles at $95^{\circ} \mathrm{C}$ for $40 \mathrm{~s}, 53^{\circ} \mathrm{C}$ for $50 \mathrm{~s}$, and $72^{\circ} \mathrm{C}$ for $50 \mathrm{~s}$, with a final extension at $72^{\circ} \mathrm{C}$ for $7 \mathrm{~min}$. The final volume of the reaction remained at $50 \mu \mathrm{L}$. All reactions were carried out using a positive (sample positive for Leishmania, DNA provided by FIOCRUZ) and a negative control (ultrapure water).

\section{PCR-RFLP}

The samples positive for Leishmania spp. were subjected to analysis by PCR-RFLP, using restriction enzyme HaeIII, following the protocol of the Molecular Procedures Manual [5]. Next, electrophoresis was performed in 3\% agarose gel in 1x TAE buffer, 70V, 150 $\mathrm{mA}$ for $1 \mathrm{~h}$, and later stained with $5 \mu \mathrm{g} / \mathrm{mL}$ of $S Y B R^{\circledR}$ Safe DNA Gel Stain ${ }^{8}$ to allow the use of an ultraviolet transilluminator (LPIX, Loccus Biotechnology $\left.{ }^{\circledR}\right)^{9}$ to compare the bands generated in the electrophoresis.

\section{PCR Leishmania infantum (species-specific)}

The designed primers RV1 5' CTTTTCTGGTCCCGCGGGTAGG 3' and RV2 5' CACCTGGCCTATTTTACACCA 3' have been used, with expected product of $145 \mathrm{pb}$ [13].

The reaction for DNA amplification was performed using $3 \mu \mathrm{L}$ of DNA template and added to a tube containing $0.2 \mu \mathrm{L}$ of Taq DNA polymerase ${ }^{4}$ at 2 $\mu \mathrm{L}$ for each initiator, $1 \mathrm{x}$ buffer containing $\mathrm{MgCl}_{2} 2.5$ $\mu \mathrm{L}, 1 \mu \mathrm{L} \mathrm{Mg}, 1 \mu \mathrm{L}$ DNTP and $13.3 \mu \mathrm{L}$ of ultrapure water. Amplification conditions on the thermal cycler $\left(\text { Biocycler }{ }^{\circledR}\right)^{7}$ included: initial denaturation at $95^{\circ} \mathrm{C}$ for $3 \mathrm{~min}$, followed by 35 cycles at $95^{\circ} \mathrm{C}$ for $40 \mathrm{~s}, 59^{\circ} \mathrm{C}$ for $50 \mathrm{~s}$, and $72^{\circ} \mathrm{C}$ for $50 \mathrm{~s}$, with final extension at $72^{\circ} \mathrm{C}$ for $7 \mathrm{~min}$. All the reactions were performed with a positive (sample positive for Leishmania infantum provided by FIOCRUZ) and a negative control (ultrapure water).

\section{Electrophoresis}

The results for both amplifications were analyzed in agarose gel electrophoresis $2 \%$ in $1 \mathrm{x}$ TAE buffer, subsequently stained with $4.5 \mu \mathrm{g} / \mathrm{mL}$ of $S Y B R^{\circledR}$ Safe DNA Gel Stain ${ }^{8}$ and viewed by means of an ultraviolet transilluminator (LPIX, Loccus Biotechnology $\left.{ }^{\circledR}\right)^{9}$.

Statistical analysis

The data were analyzed using descriptively statistics.

\section{RESULTS}

Among the 198 dogs evaluated, 48 (24.2\%) animals showed clinical signs compatible with canine visceral leishmaniasis, and the other $150(75.8 \%)$ were asymptomatic at the time of sample collection.

Among the 198 blood samples analyzed by the two PCR techniques, four tested positive for Leishmania infantum, two of them symptomatic and two asymptomatic, one male and one female in each group, which are described further below.

Regarding the clinical hematological signs of the dogs which tested positive, animal one had diffuse alopecia, ulcerated lesions on the tip of the ears (Figure 1), uveitis, onychogryphosis and cachexia. The animal also showed anemia and neutrophilic leukocytosis. Animal two presented alopecia, pustules, crusting, diffusely spread erythema (Figure 2) and anemia, hyperproteinemia, thrombocytopenia and azotemia.

In the two dogs that were asymptomatic but tested positive via PCR, the hematological and biochemical changes observed included: for animal three - anemia, hyperproteinemia, thrombocytopenia, neutrophilic leukocytosis and azotemia; and for animal four - hyperproteinemia and neutrophilic leukocytosis.

\section{DISCUSSION}

The prevalence of canine visceral leishmaniasis in the city of Jequié, state of Bahia, found in the present study was $2 \%$, compared to $20 \%$ found in a 


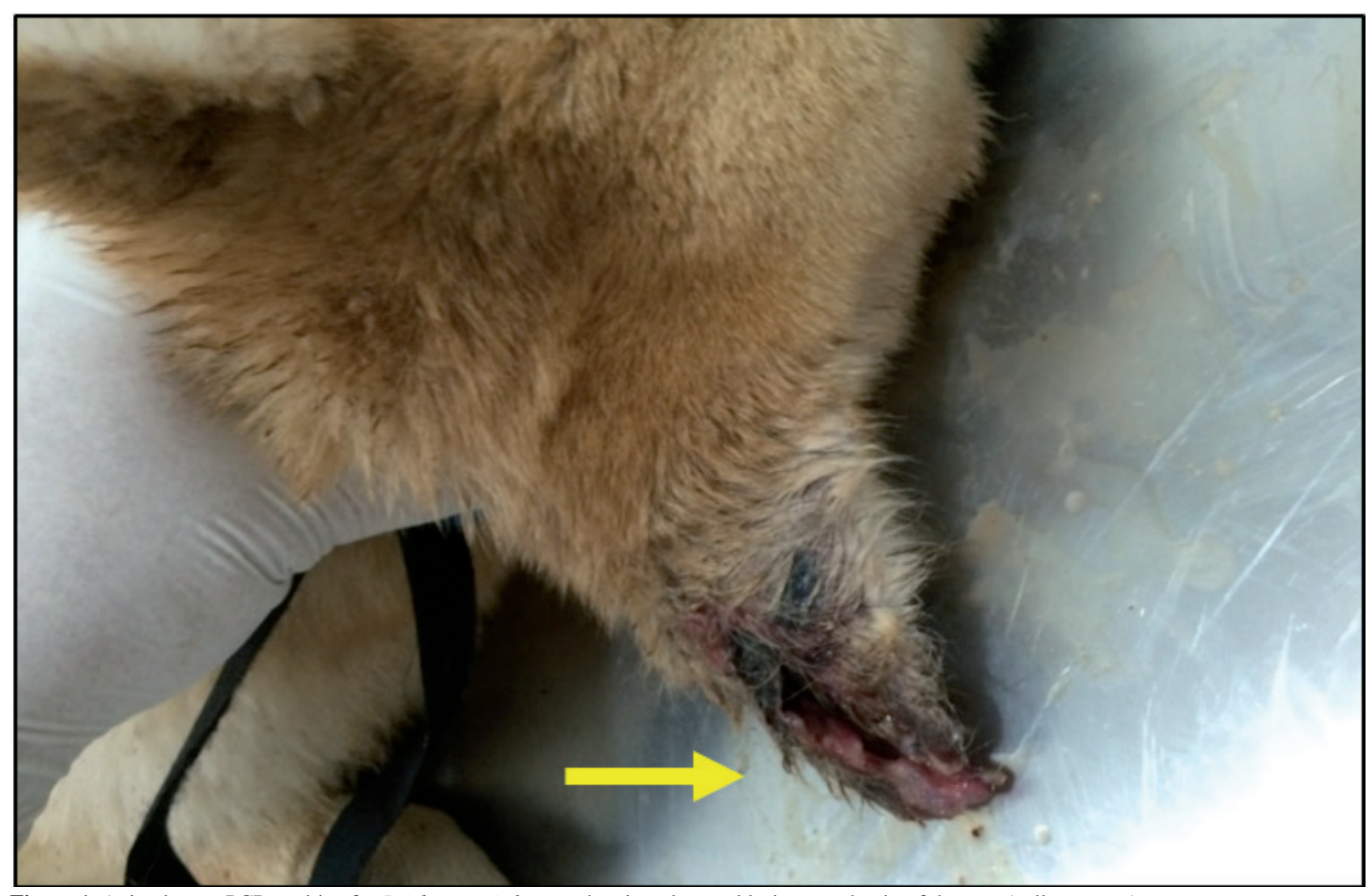

Figure 1. Animal one - PCR positive for Leishmania infantum showing ulcerated lesions on the tip of the ears (yellow arrow).

study carried out in 1996 using a sample of 1681 dogs diagnosed by serology [19]. The diagnostic technique chosen for this study was the PCR, a molecular tool that has been widely used in research because it is a technique with high effectiveness, sensitivity and specificity [17]. A larger number of positive animals is expected from other serological techniques when compared to PCR, because in endemic regions such as the one studied herein, most dogs are expected to be in the chronic phase of the disease, reducing the parasitic load in the blood, and thus reducing the chances of detection by PCR. On the other hand, the serological tests can have cross-reaction with other pathogens such as Trypanosoma cruzi thus increasing the number of positive cases [15].

In this study, blood collection was the method chosen for PCR evaluation. It is known that splenic, hepatic, spinal cord or lymph node samples are the most suitable for PCR in endemic locations. However, this type of collection requires general anesthesia and becomes a limiting factor for the research field, since most of the owners of the animals refuse this type of procedure [7].

Because the clinical signs for visceral leishmaniasis are multisystemic and very variable, this study shows that clinical diagnosis alone is insufficient for

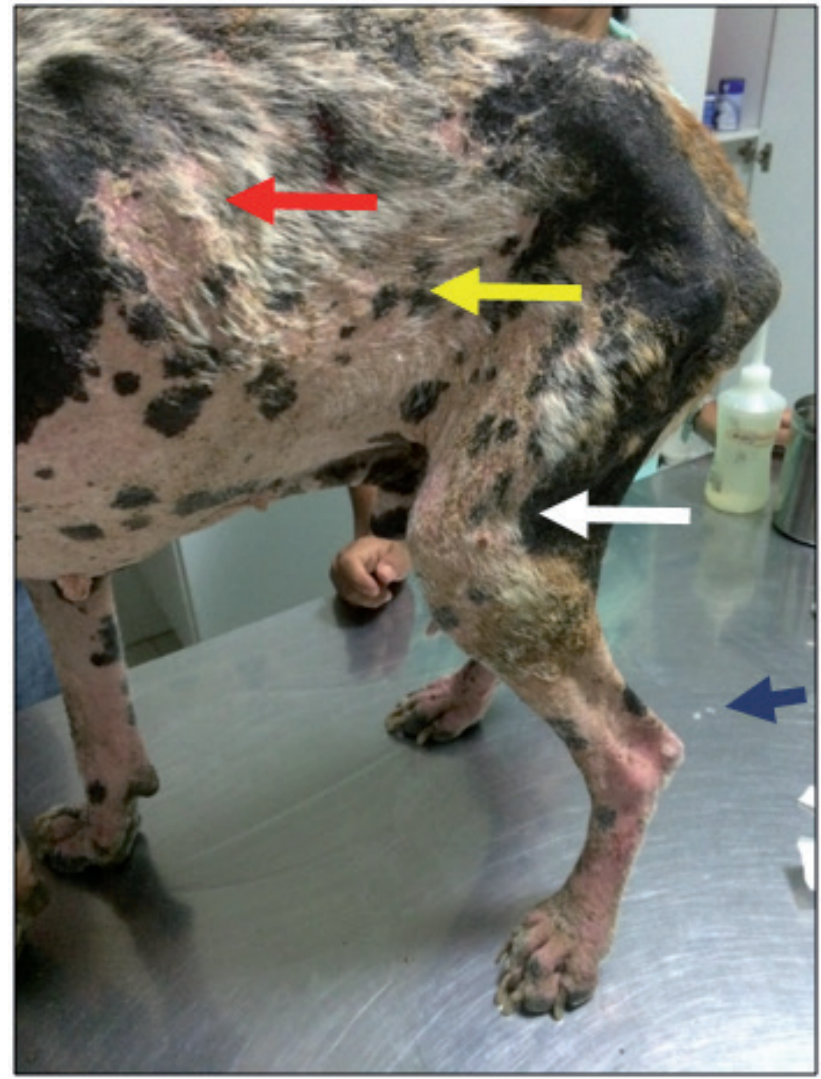

Figure 2. Animal two - PCR positive for Leishmania infantum showing prominence of the pelvic bones indicating cachexia (red arrow), alopecia (yellow arrow), epidermal debris (scaling) on the examination table (blue arrow) and pustules (white arrow). 
use as a default on leishmaniasis cases [3]. Therefore, when the clinicians encounter a case of an animal showing clinical signs compatible with this disease, which may lead them to diagnosis they should request specific tests before giving their final diagnosis. This is true even when the case comes from regions that are endemic for canine visceral leishmaniasis, since further testing can permit the clinical to avoid prematurely discarding possible differential diagnoses such as ehrlichiosis, babesiosis, skin diseases, among others [14]. In endemic areas, even dogs that do not show clinical signs can be positive and potential reservoirs of the parasite. It is therefore necessary to always include complementary laboratory exams for a definitive diagnosis, in addition to epidemiological evaluations to review data.

All positive dogs showed hematological and biochemical changes. The reduced red blood cell numbers to levels indicative of anemia occur mainly due to spinal cord dysfunctions that occur in the presence of parasitism by Leishmania. These spinal cord issues cause decreased hematopoiesis, and the production of immunosuppressive cytokines has also been reported $[1,20]$. Hyperproteinemia is commonly observed in cases of leishmaniasis due to the high production of antibodies, and this change was observed in three of the four positive animals [9].

Unlike the results found in this study, other authors have reported a decrease in the number of leukocytes, and have attributed this change to the intense tropism and intracellular parasitism of leukocytes by parasites, leading to the destruction of the cells, as well as to an increase in the recruitment of white blood cells by the spleen $[1,21]$. The neutrophilic leukocytosis observed in this study suggests that these animals were in a moment of intense cellular immune response overriding the destruction of leucocytes, or perhaps some other secondary active bacterial infection, such as dermatitis with pustules in symptomatic animals.

On the other hand, as per the results of the biochemical tests, only one animal testing positive for $L$. infantum showed increased BUN. According to other authors, renal involvement is rarely noticed - mostly limited only to cases in which the disease is severe. In these cases of immune-mediated glomerulopathy, the damage is secondary to antigen-antibody deposition. $[6,22]$. However, due to the age of this one animal with elevated BUN (eight years), pre-existing age related chronic renal disease cannot be ruled out.

In fact, the hematological and biochemical changes are nonspecific, and more specific examination is essential, be it parasitological, serological or molecular.

The results of the present study are therefore important: the animals that participated in this study are semi-domiciled in neighborhoods on the outskirts of the city where a high rate of occurrence of this disease has been previously observed in the region; moreover our results reinforce the important epidemiological truth that asymptomatic, positive animals are present in the canine population.

\section{CONCLUSION}

The city of Jequié has low occurrence of animals testing positive for Leishmania infantum using PCR evaluation of the leukocytes separated from whole blood samples.

It was not possible to establish a relationship between the molecular positivity for Leishmania infantum in dogs with the clinical signs and/or the studied hematological and biochemical analysis, but the presence of positive animals without clinical signs must be emphasized.

\section{MANUFACTURERS}

${ }^{1}$ Horiba Instruments Brasil Ltda. Jundiaí, SP, Brazil.

${ }^{2}$ Laborclin produtos para Laboratórios Ltda. Pinhais, PR, Brazil.

${ }^{3}$ Carl Zeiss. Oberkochen, BW, Germany.

${ }^{4}$ Labtest Diagnóstica S.A. Lagoa Santa, MG, Brazil.

${ }^{5}$ Bioplus produtos para Laboratórios Ltda. Barueri, SP, Brazil.

${ }^{6}$ Promega Corporation. Madison, WI, USA.

${ }^{7}$ Applied Biosystems. Foster City, CA, USA.

${ }^{8}$ Invitrogen Corporation. Carlsbad, CA, USA.

${ }^{9}$ Loccus do Brasil Ltda. São Paulo, SP, Brazil.

Funding. The present research was supported by the Fundação de Amparo à Pesquisa do Estado da Bahia - FAPESB (Foundation for Research Support of the State of Bahia) and by the State University of Santa Cruz (UESC).

Acknowledgements. The authors would like to thank the Oswaldo Cruz Foundation (FIOCRUZ) for providing positive controls for the study.

Ethical approval. The study was approved by the Ethics Committee for the Use of Animals from the State University of Santa Cruz (Protocol no. 018/2012).

Declaration of interest. The authors report no conflicts of interest. The authors are solely responsible for the content and the writing of this paper. 


\section{REFERENCES}

1 Alvar J., Cañavate C., Molina R., Moreno J. \& Nieto J. 2004. Canine leishmaniasis. Advances in Parasitology. 57(3): 1-88.

2 Alves W.A. \& Bevilacqua P.D. 2004. Reflexões sobre a qualidade do diagnóstico da leishmaniose visceral canina em inquéritos epidemiológicos: o caso da epidemia de Belo Horizonte, Minas Gerais, Brasil 1993-1997. Caderno de Saúde Pública. 20(1): 259-265.

3 Barbosa V.T., Silva M.A.G., Sousa M.G., Gering A.P., Santos H.D. \& Laus J.L. 2012. Detecção de formas amastigotas em exame parasitológico de esfregaço obtido a partir de suabe conjunctival de cães com leishmaniose visceral. Arquivo Brasileiro Medicina Veterinária Zootecnia. 64(6): 1465-1470.

4 Brasil - Ministério da Saúde. 2003. Manual de Vigilância e Controle da Leishmaniose Visceral. Brasília: Editora Ministério da Saúde, 120p.

5 Brasil - Instituto Oswaldo Cruz. 2009. Manual Molecular Procedures. In: Leishmaniasis Epidemiology Network South America (Rio de Janeiro, Brazil). 53p.

6 Ciaramella P., Oliva G., De Luna R., Gradoni L., Ambrosio R., Cortese L., Scalone A. \& Persechino A. 1997. Retrospective clinical study of canine leishmaniasis in 150 dogs naturally infected by Leishmania infantum. Veterinary Record. 141(1): 539-543.

7 Dye C., Vidor E. \& Dereure J. 1993. Sorological diagnosis of leishmaniasis: on detecting infection as well as disease. Epideliology and Infection. 110(3): 647-656.

8 El Tail N.O., Osman O.F., El Fari M., Presber W. \& Schõnian G. 2000. Genetic heterogeneity of ribosomal internal transcribed spacer in clinical samples of Leishmania donovani spotted on filter paper as revealed by single-strand conformation polymorphisms and sequencing. Royal of Society Tropical Medicine and Hygiene. 94(1): 570-575.

9 Ferrer L.M. 1992. Leishmaniasis In: Kirk R.W. \& Bonagura J.D. (Eds). Kirk's Current Veterinary Therapy XI: Small Animal Practice. 11th edn. St. Louis: Saunders, 1392p.

10 Instituto Brasileiro de Geografia e Estatística (IBGE). 2010. Censo demográfico. Avaible at <http://cod.ibge.gov. br/W1P> [Accessed online in July 2014].

11 Jain N.C. 1993. Essentials of Veterinary Hematology. 5th edn. Philadelphia: Lea and Febiger, 417p.

12 Kaneko J.J., Harvey J.W. \& Bruss M.L. 1997. Clinical Biochemistry of domestic Animals. 5th edn. St. Louis: Saunders, 932p.

13 Le Fichoux Y., Quaranta J., Aufeuvre J., Lelievre A., Marty P., Suffia I., Rousseau D. \& Kubar J. 1999. Occurrence of Leishmania infantum parasitemia in asymptomatic blood donors living in an area of endemicity in Southern France. Journal of Clinical Microbiology. 37(6): 1953-1957.

14 Llera J.L.G., García M.L.L., Reinoso E.M. \& González R.D.V. 2002. Differential sorological testing by simultaneous indirect immunofluorescent antibody test in canine leishmaniosis and ehrlichiosis. Veterinary Parasitology.109(1): 185-190.

15 Luciano R.M., Lucheis S.B., Troncarelli M.Z. \& Luciano D.M. 2009. Avaliação da reatividade cruzada entre antígenos de Leishmania spp. e Trypanosoma cruzi na resposta sorológica de cães pela técnica de imunofluorescência indireta (RIFI). Brazilian Journal of Veterinary Research and Animal Science. 46(3): 181-187.

16 Marzochi M.C.A., Coutinho S.G., Souza W.J.S., Toledo L.M., Grimaldi-Junior G., Momen H., Pacheco R.S., Sabroza P.C., Souza M.A., Rangel-Junior F.B. \& Tramontano N.C. 1985. Canine Visceral Leishmaniasis in Rio de Janeiro, Brazil: clinical, parasitological, therapeutical and epidemiological findings (1977-1983). Memórias do Instituto Osvaldo Cruz. 80(3): 349-357.

17 Melo M.N. 2004. Leishmaniose visceral no Brasil: desafios e perspectivas. Revista Brasileira de Parasitologia Veterinária. 7(3): 338-349.

18 Molina R., Amela C., Nieto J., San-Andrés M., González F., Castillo J.A., Lucientes J. \& Alvar J. 1994. Infectivity of dogs naturally infected with Leishmania infantum to colonized Phlebotomus perniciosus. Transactions Royal of Society Tropical Medicine and Higiene. 88(1): 491-493.

19 Paranhos-Silva M., Freitas L.A., Santos W.C., Grimaldi-Junior G., Pontes-de-Carvalho L.C.P. \& Oliveira-dosSantos A.J. 1996. A cross-sectional serodiagnostic survey of canine leishmaniasis dueto Leishmania chagasi. The American Journal of Tropical Medicine and Hygiene. 55(1): 39-44. 
20 Pinelli E., Killick-Kendrick R., Wagenaar J., Bernardina W., Del Real G. \& Ruitenberg G.J. 1994. Cellular and humoral immune responses in dogs experimentally and naturally infected with Leishmania infantum. Infection and Immunity. 62(1): 229-235.

21 Reis A.B., Martins-Filho O.A., Teixeira-Carvalho A., Carvalho M.G., Mayrink W., França-Silva J.C., Giunchetti R.C., Genaro O. \& Corrêa-Oliveira R. 2006. Parasite density and impaired biochemical/hematological status are associated with severe clinical aspects of canine visceral leishmaniasis. Research in Veterinary Science. 81(1): 68-75.

22 Silva F.S. 2007. Patologia e patogênese da leishmaniose visceral canina. Revista Trópica-Ciências Agrárias e Biológicas. 1(1): 20.

23 Sousa V.R.F. \& Almeida A.B.P.F. 2008. Co-Infecção entre leishmaniose visceral e ehrlichiosemonocítica em cães de Cuiabá, Mato Grosso. Acta Scientiae Veterinariae. 36(2): 113-117. 